УДК 811.[163.2+166.52]'367.622.22:81'246.2

DOI: $10.24144 / 2617-3921.2019 .17 .88-95$

Dominika Mohňanská

Mgr., doctoral student University of Pavol Jozef Šafárik in Košice, Faculty of Arts

Department of British and American Studies Slovakia, 00421911931210 , dominikamohnanska@gmail.com https://orcid.org/0000-0001-5884-8440

\title{
Experimental Research into the Use of Diminutives by Slovak-Hungarian Bilingual Speakers
}

Анотація. Стаття присвячена вживанню зменшувальних іменників у словачькій та угорській мовах, зокрема їхнього застосування у мовленні моно та білінгвів. Увага звертається як на існування демінутивів у досліджуваних мовах, так і на специифіці їхнього утворення. Проведений експериментальний аналіз ставив своєю метою підтвердити або спростувати існуюче твердження, що словаџько-угорські білінгви вживають у своєму мовленні більше демінутивів в угорській мові, ніж угорські мовці із-за впливу словачької мови, щзо має багату оцінну морфологію.

Ключові слова: демінутиви, словаџька мова, угорська мова, білінгви, мовлення, морфологія.

Abstract. The existence of diminutives differs among languages. This paper focuses on the use of diminutives in two languages, Slovak and Hungarian. The investigated languages represent two language families, for this reason the analysis is more comprehensive. The paper is aimed at an experimental research 
in the field of evaluative morphology. The examination concentrates on the number of the occurred diminutives in the speech of the mono- and bilingual participants of the research. The paper deals with the word class of the diminutives and the word formation processes of diminution as well. The goal of this paper is to prove or disprove the assumption that the Slovak-Hungarian bilingual speakers use more diminutives in Hungarian than the monolingual Hungarian speakers, because of the influence of the Slovak language which has a rich evaluative morphology.

Keywords: diminutives, evaluative morphology, diminution, bilingualism, Slovak language, Hungarian language

\section{Introduction}

The presence of diminutives varies from language to language. While some languages have a high degree of diminutive usage, languages without any type of diminution exist as well. This paper is aimed at offering an overview of an experimental research investigating two languages from two language families, that of Slovak from the Indo-European language family and that of Hungarian from the Uralic language family. Both examined languages use diminutives, although the process of diminution is more frequent in the Slovak language [1, p. $105,106]$. The research was conducted among bilingual and monolingual speakers with focus on the use of diminutives in their speech. The goal of this paper is to prove or disprove the assumption that the Slovak-Hungarian bilingual speakers use more diminutives in Hungarian than the monolingual Hungarian speakers, because of the impact of the Slovak language which has a rich evaluative morphology.

\section{Methodology}

As data collection is one of the most essential components of any research the following lines discuss the method of data gathering and the research methods as well. The experimental research was carried out among Slovak-Hungarian bilingual and monolingual speakers and the dialogues between the bilingual and monolingual parents and their children were analysed with focus on the use of diminutives. The bilingual families participating in the study were provided with role-play scenarios for their dialogues, which they were supposed to act out both in Slovak and in Hungarian in order to achieve a valid comparison of the two languages in a similar situation. The investigated topics and situations were as follows:

- $\quad$ Time for bed and sleeping

- $\quad$ Time for dinner

- $\quad$ Time for learning or time for playing

The participants of the research were not aware of the fact that the analysis focuses on the use of diminutives, which ensured that they were not concentrating on the diminutives during their speech. Another very important feature of the research is the fact that the dialogues were recorded with pauses. The recordings 
within one family were realized on three different days. In the case of the families with both bilingual and monolingual parents the monolingual member of the family was not present when the bilingual member was recorded and vice versa. This circumstance excluded the parents' influence on each other, although we can talk about the influence of the investigator. In order to reduce the effect of the observer's paradox the chosen participants were individuals I am acquainted with and with whom I often spend time.

\section{Analysis}

\subsection{Summary of the results}

The goal of this chapter is to offer an overview of the results of the analysis which was carried out with the help of five participants, more specifically five people from three families. The following table lists the examined speakers from the point of view of mono- and bilingualism. It also explains the abbreviations that are used in the discussion part of this paper.

\begin{tabular}{|l|l|lr|}
\hline Family 1 & B Mother 1- bilingual & $\begin{array}{l}\text { M Father 1- Slovak } \\
\text { monolingual }\end{array}$ \\
\hline Family 2 & B Mother 2- bilingual & $\begin{array}{l}\text { M Father 2- Slovak } \\
\text { monolingual }\end{array}$ \\
\hline Family 3 & $\begin{array}{l}\text { M Mother 3- Hungarian } \\
\text { monolingual }\end{array}$ & \multicolumn{2}{|l|}{} \\
\hline
\end{tabular}

Table 1 Abbreviations used in the analysis

This chapter discusses the use of diminutives in the investigated two languages by the bilingual and monolingual participants of the research. The analysis centers on the occurrence of diminutives, the type of diminutive formation, the applied word-formation process and the word class of the diminutivized word.

Firstly, the results of the Slovak dialogues are summarized. The table below shows that the bilingual speakers of the research used more diminutives during the Slovak dialogues than the monolingual Slovak speakers.

\begin{tabular}{|c|c|c|}
\hline Situation & $\begin{array}{c}\text { The total number of } \\
\text { dim. Occurrence in } \\
\text { Slovak by bilingual } \\
\text { speakers }\end{array}$ & $\begin{array}{c}\text { The total number of } \\
\text { dim. Occurrence in } \\
\text { Slovak by monolingual } \\
\text { speakers }\end{array}$ \\
\hline $\begin{array}{c}\text { "Time for bed and } \\
\text { sleeping" }\end{array}$ & 14 & 5 \\
\hline "Time for dinner" & 12 & 8 \\
\hline $\begin{array}{c}\text { "Time for playing" or } \\
\text { "Time for learning" }\end{array}$ & 12 & 6 \\
\hline Sum of the 3 situations & 38 & 19 \\
\hline
\end{tabular}

Table 2 Summary 
Regarding the type of diminutive formation only the synthetic type was identified. During the analysis of the Slovak dialogues, two processes were observed; suffixation and shortening, out of which suffixation was the most frequently applied one. The bilinguals formed all 22 diminutives by suffixation. In comparison, the monolingual speakers used suffixation in 13 words out of 14, with the process of shortening represented by one example only.

\begin{tabular}{|c|c|c|}
\hline $\begin{array}{c}\text { Type of dim. } \\
\text { Formation }\end{array}$ & $\begin{array}{c}\text { Number of dim. In Slovak } \\
\text { by bilingual speakers }\end{array}$ & $\begin{array}{c}\text { Number of dim. In Slovak } \\
\text { by monolingual speakers }\end{array}$ \\
\hline Synthetic & 22 & 14 \\
\hline • Suffixation & 22 & 13 \\
\hline - shortening & - & 1 \\
\hline Analytical & - & - \\
\hline
\end{tabular}

Table 3The types of diminutive formation

The third point of comparison is the word class of the diminutivized words. The categories of nouns, verbs and adverbs were identified in the Slovak dialogues of both bilingual and monolingual participants. In both cases the category of nouns was represented by the highest number of diminutives. The table below provides an overview of the word-class categories represented in the results.

\begin{tabular}{|c|c|c|}
\hline $\begin{array}{c}\text { Word class of } \\
\text { diminutives }\end{array}$ & $\begin{array}{c}\text { Number of dim. In Slovak } \\
\text { by bilingual speakers }\end{array}$ & $\begin{array}{c}\text { Number of dim. In Slovak } \\
\text { by monolingual speakers }\end{array}$ \\
\hline Nouns & 19 & 11 \\
\hline Verbs & 2 & 2 \\
\hline Adverbs & 1 & 1 \\
\hline
\end{tabular}

Table 4 The word classes of diminutives

The Table 5 offers a summary of the results of the Hungarian dialogues. The following table illustrates the total number of diminutive occurrence. As demonstrated, the difference between the B Mother 1 and the M Mother 3 is sizable; however, there is hardly any difference between the B Mother 2 and $\mathrm{M}$ Mother 3.

\begin{tabular}{|c|c|c|c|}
\hline Situation & $\begin{array}{c}\text { The total number of } \\
\text { dim. occurrence in } \\
\text { Hungarian by B } \\
\text { Mother 1 }\end{array}$ & $\begin{array}{c}\text { The total number } \\
\text { of dim. } \\
\text { occurrence in } \\
\text { Hungarian by B } \\
\text { Mother 2 }\end{array}$ & $\begin{array}{c}\text { The total } \\
\text { number of dim. } \\
\text { occurrence in } \\
\text { Hungarian by M } \\
\text { Mother 3 }\end{array}$ \\
\hline $\begin{array}{c}\text { "Time for bed and } \\
\text { sleeping" }\end{array}$ & 12 & 5 & 5 \\
\hline "Time for dinner" & 5 & 2 & 2 \\
\hline
\end{tabular}




\begin{tabular}{|c|c|c|c|}
\hline $\begin{array}{c}\text { "Time for playing" } \\
\text { or "Time for } \\
\text { learning" }\end{array}$ & 6 & 1 & 4 \\
\hline $\begin{array}{c}\text { Sum of the } 3 \\
\text { situations }\end{array}$ & 23 & 8 & 11 \\
\hline
\end{tabular}

Table 5 Summary

The Table 6 illustrates the type of diminutive formation and the word formation processes of diminution. It is evident that the process of suffixation was the most frequently applied in all three cases.

\begin{tabular}{|c|c|c|c|}
\hline $\begin{array}{c}\text { Type of dim. } \\
\text { formation }\end{array}$ & $\begin{array}{c}\text { Number of dim. } \\
\text { in Hungarian } \\
\text { by B Mother 1 }\end{array}$ & $\begin{array}{c}\text { Number of dim. } \\
\text { in Hungarian by } \\
\text { B Mother 2 }\end{array}$ & $\begin{array}{c}\text { Number of dim. } \\
\text { in Hungarian by } \\
\text { M Mother 3 }\end{array}$ \\
\hline Synthetic & 11 & 4 & 10 \\
\hline - Suffixation & 10 & 3 & 9 \\
\hline - shortening & 1 & - & - \\
\hline - infixation & - & 1 & 1 \\
\hline Analytical & 1 & - & - \\
\hline
\end{tabular}

Table 6 The types of diminutive formation

In order to provide the summary of the results, the table below offers an overview of the occurred diminutives from the perspective of word classes. The results show that the monolingual Hungarian speaker used the widest scale of word classes; this is supported by the fact that the M Mother 3 used 3 word - classes in the course of the three dialogues.

\begin{tabular}{|c|c|c|c|}
\hline $\begin{array}{c}\text { Word - class of } \\
\text { diminutives }\end{array}$ & $\begin{array}{c}\text { Number of dim. } \\
\text { in Hungarian by } \\
\text { B Mother 1 }\end{array}$ & $\begin{array}{c}\text { Number of dim. } \\
\text { in Hungarian by } \\
\text { B Mother 2 }\end{array}$ & $\begin{array}{c}\text { Number of dim. } \\
\text { in Hungarian by } \\
\text { M Mother 3 }\end{array}$ \\
\hline Nouns & 11 & 2 & 7 \\
\hline Verbs & 1 & 2 & 2 \\
\hline Adverbs & - & - & 0 \\
\hline Adjective & - & - & 1 \\
\hline
\end{tabular}

Table 7 The word classes of diminutives

\subsection{Comparison of the results}

In pursuit of the aim of this paper it is unavoidable to compare the previously summarized research results. The following tables provide a comparison of the analyzed features of both investigated languages and all the examined speakers. Concerning the total number of diminutive occurrences in the three situations, the highest number was observed in the Slovak dialogues of 
bilingual speakers, while the lowest number was identified in the Hungarian language of the monolingual speaker.

\begin{tabular}{|c|c|c|c|c|}
\hline Situation & $\begin{array}{c}\text { The total } \\
\text { number of } \\
\text { dim. } \\
\text { occurrence in } \\
\text { Slovak by } \\
\text { bilingual } \\
\text { speakers }\end{array}$ & $\begin{array}{c}\text { The total } \\
\text { number of } \\
\text { dim. } \\
\text { occurrence in } \\
\text { Hungarian by } \\
\text { bilingual } \\
\text { speakers }\end{array}$ & $\begin{array}{c}\text { The total } \\
\text { number of dim. } \\
\text { occurrence in } \\
\text { Slovak by } \\
\text { monolingual } \\
\text { speakers }\end{array}$ & $\begin{array}{c}\text { The total } \\
\text { number of dim. } \\
\text { occurrence in } \\
\text { Hungarian by } \\
\text { the monolingual } \\
\text { speaker }\end{array}$ \\
\hline $\begin{array}{c}\text { "Time for } \\
\text { bed and } \\
\text { sleeping" }\end{array}$ & 14 & 17 & 5 & 5 \\
\hline $\begin{array}{c}\text { "Time for } \\
\text { dinner" }\end{array}$ & 12 & 7 & 8 & 2 \\
\hline $\begin{array}{c}\text { "Time for } \\
\text { playing" } \\
\text { or } \\
\text { learning }\end{array}$ & 12 & 7 & 6 & 4 \\
\hline $\begin{array}{c}\text { All the 3 } \\
\text { situations } \\
\text { together }\end{array}$ & 38 & 31 & 19 & 11 \\
\hline
\end{tabular}

Table 8 Comparison

The Table 9 illustrates the occurred types of word formation processes used in diminution. From the three processes of synthetic diminutive formation the process of suffixation was the most frequently applied in both languages by all the examined bilinguals and monolinguals. The processes of infixation and shortening were represented only by a few examples and only one diminutive was formed analytically in the course of the examined dialogues. The widest scale of the word - formation processes was used in Hungarian by the bilingual speakers of the research.

\begin{tabular}{|c|c|c|c|c|}
\hline $\begin{array}{c}\text { Type of dim. } \\
\text { formation }\end{array}$ & $\begin{array}{c}\text { Number } \\
\text { of dim. in } \\
\text { Slovak by } \\
\text { bilingual } \\
\text { speakers }\end{array}$ & $\begin{array}{c}\text { Number of } \\
\text { dim. in } \\
\text { Hungarian } \\
\text { by bilingual } \\
\text { speakers }\end{array}$ & $\begin{array}{c}\text { Number of } \\
\text { dim. in } \\
\text { Slovak by } \\
\text { monolingual } \\
\text { speakers }\end{array}$ & $\begin{array}{c}\text { Number of } \\
\text { dim. in } \\
\text { Hungarian } \\
\text { by the } \\
\text { monolingual } \\
\text { speaker }\end{array}$ \\
\hline Synthetic & 22 & 15 & 14 & 10 \\
\hline$\bullet$ Suffixation & 22 & 13 & 13 & 9 \\
\hline$\bullet$ Infixation & - & 1 & - & 1 \\
\hline - Shortening & - & 1 & 1 & - \\
\hline Analytical & - & 1 & - & - \\
\hline
\end{tabular}

Table 9 The word formation processes 
The following table shows the proportion of the word classes of the occurred diminutives. From the numbers it is evident that the majority of the occurred diminutives was formed from nouns. The nouns were the most frequent subjects of the process of diminution in both languages and by all the examined speakers. The category of verbs was represented by 9 diminutives, while the class of adverbs was identified twice and that of adjectives only once.

\begin{tabular}{|c|c|c|c|c|}
\hline $\begin{array}{c}\text { Word - } \\
\text { class of } \\
\text { diminutives }\end{array}$ & $\begin{array}{c}\text { Number of } \\
\text { dim. in } \\
\text { Slovak by } \\
\text { bilingual } \\
\text { speakers }\end{array}$ & $\begin{array}{c}\text { Number of } \\
\text { dim. In } \\
\text { Hungarian by } \\
\text { bilingual } \\
\text { speakers }\end{array}$ & $\begin{array}{c}\text { Number of } \\
\text { dim. in Slovak } \\
\text { by monolingual } \\
\text { speakers }\end{array}$ & $\begin{array}{c}\text { Number of } \\
\text { dim. in } \\
\text { Hungarian } \\
\text { by } \\
\text { monolingual } \\
\text { speakers }\end{array}$ \\
\hline Nouns & 19 & 13 & 11 & 7 \\
\hline Verbs & 2 & 3 & 2 & 2 \\
\hline Adverbs & 1 & - & 1 & - \\
\hline Adjective & - & - & - & 1 \\
\hline
\end{tabular}

Table 10 The word classes of the diminutives

\section{Discussion}

As it was already stated the main objective of this paper is to prove or disprove the assumption that the Slovak-Hungarian bilingual speakers use more diminutives in Hungarian than the monolingual Hungarian speakers. The following table summarizes the total number of diminutive occurrences in the three investigated dialogues of the analyzed participants.

\begin{tabular}{|c|c|c|}
\hline Speakers & $\begin{array}{c}\text { The total number of } \\
\text { diminutive occurrence in } \\
\text { Slovak }\end{array}$ & $\begin{array}{c}\text { The total number of } \\
\text { diminutive occurrences in } \\
\text { Hungarian }\end{array}$ \\
\hline M Father 1 & 8 & - \\
\hline M Father 2 & 11 & - \\
\hline M Mother 3 & - & 11 \\
\hline B Mother 1 & 26 & 23 \\
\hline B Mother 2 & 13 & 8 \\
\hline
\end{tabular}

Table 11 Summary

In Hungarian, the monolingual participant used 11 diminutives and the bilingual participants 23 and 8 . In the case of the B Mother 1 it is evident that our assumption is true, because the total number of diminutive occurrence in Hungarian is higher than the M Mother 3's number. On the other hand, if we observe the Hungarian language of the B Mother 2, the number is lower than that 
of the M Mother 3. Considering these outcomes, we can conclude that our assumption was proved only partially.

In order to prove or disprove our assumption unequivocally, further research is suggested, which should analyze more participants in more situations in order to get a more comprehensive study.

\section{LITERATURE}

1. Körtvélyessy L. 2015. Evaluative Morphology from a Cross - Linguistic Perspective. Newcastle upon Tyne: Cambridge Scholars Publishing, 2015. $277 \mathrm{p}$. 